\title{
Subpopulations of granulosa cells within the human ovarian follicle
}

\author{
G. M. Hartshorne \\ Bourn Hall Clinic, Bourn, Cambridge, CB3 7TR, UK; and The Physiological Laboratories, \\ University of Cambridge, Downing Street, Cambridge CB2 $3 E G, U K$
}

\begin{abstract}
Summary. Human follicular cells were separated according to their isopycnic densities. Three populations were isolated and identified in terms of their secretion of progesterone and oestradiol. Cells in the least dense population secreted approximately $60 \%$ as much progesterone and $20 \%$ as much oestradiol per cell as did cells in the two denser bands.

It is proposed that cumulus cells compose the least dense band and that another band may be made up of antral cells.
\end{abstract}

Keywords: man; granulosa cell; subpopulation; steroid; density gradient

\section{Introduction}

The granulosa cells which constitute the ovarian follicle have many and diverse functions throughout the menstrual cycle but the distribution of these properties amongst the cells is unclear. Differences between peripheral and cumulus cells include their hCG receptor densities (Amsterdam et al., 1975), antigenic determinants (Erickson et al., 1985) and production of steroids (Magnusson et al., 1982) and matrix substances such as plasminogen activator (Gilula et al., 1978), and variations in the levels of several enzymes in mural and antral cells (Zoller \& Weisz, 1978, 1979). Nevertheless, peripheral and cumulus cells have a common ancestry, arising in the mouse from the mixing of clones of cells derived from approximately 5 'precursor' granulosa cells (Telfer et al., 1988), and so differences observed amongst granulosa cells may reflect either differential positional information, resulting from interaction with the oocyte, follicular fluid, basement membrane, diffusion gradients or other cells, or variable degrees of differentiation between cells or groups of cells.

Various means of separating different subpopulations of granulosa cells from within the follicle have been tried. However, all of the reports to date have used non-primate species. The aim of this study was to investigate stimulated human granulosa cells, attempting to separate subpopulations by using isopycnic density gradient centrifugation and to define their endocrine properties.

\section{Materials and Methods}

\footnotetext{
Patient population. Granulosa cells were obtained from patients undergoing in-vitro fertilization at Bourn Hall Clinic. Ovarian stimulation protocols have been published previously (Howles et al., 1987; Macnamee et al., 1989). Of 16 patients included in this study, 3 underwent pituitary desensitization using a gonadotrophin-releasing hormone agonist (GnRH-A), buserelin (Suprefact; Hoechst, Hounslow, UK) in the luteal phase, followed by gonadotrophic stimulation (human menopausal gonadotrophin, hMG, Pergonal; follicle-stimulating hormone, FSH, Metrodin; Serono Laboratories, Welwyn Garden City, UK), 1 received short-term buserelin treatment on Days 2-4 of the follicular phase, followed by gonadotrophins, and the remaining 12 patients were given clomiphene citrate and gonadotrophins. After Day 9 of the treatment cycle, all protocols were individualized according to the patient's response.
} 
Preparation of follicular cells. Cells were aspirated from follicles of 15 patients. If possible, clear follicular fluid from each follicie was collected and stored at $-20^{\circ} \mathrm{C}$ until assayed for progesterone and oestradiol as described below. The aspirates, including cells flushed from the follicles, were centrifuged $(100 \mathrm{~g}, 5 \mathrm{~min})$ and the sedimented cells, including any contaminating blood cells, were resuspended in $0.5 \mathrm{ml} \mathrm{McCoy's} 5 \mathrm{~A}$ medium (Gibco, Uxbridge, UK) containing a mixture of penicillin $(100 \mathrm{IU} / \mathrm{ml})$, streptomycin $(100 \mu \mathrm{g} / \mathrm{ml})$ and Hepes buffer $(25 \mathrm{~mm})$. The blood cells were not removed at this stage since the subsequent gradient centrifugation would effect their separation.

Cumulus granulosa cells from 13 follicles of Patient 16 were obtained after culture for approximately $24 \mathrm{~h}$ in the presence of spermatozoa, in Earles medium supplemented with pyruvate $(0.3 \mathrm{~mm})$ and human serum albumin $(0.4 \%)$. These cumulus cells surround the egg and were separated manually from the follicular aspirate before culture. They may therefore also contain minor contamination with other follicular cells and blood. The cumulus cells were gently scraped from the surface of the culture vessel and the media containing the cells removed and pooled. The pool was centrifuged and pelleted cells were resuspended in McCoy's 5A medium as above. Thereafter, the suspension was treated exactly as the follicular aspirates.

To obtain a single cell suspension, the preparation was aspirated vigorously with a Pasteur pipette, followed by similar treatment with an automatic pipette holding a sterilized plastic tip. Then the suspension was passed 6-12 times through a 23-gauge needle and viewed microscopically. If clumps of more than 2 or 3 cells were still present, the suspension was flushed through sterile gauze (Boots, Cambridge, UK) which, while causing substantial loss of cells, removed almost all remaining clumps. An aliquant was counted using a haemocytometer and viability was assessed by exclusion of trypan blue dye $(0.2 \%)$. Blood cells could be easily distinguished from the larger, more granular follicular cells and viability was expressed as the number of follicular cells excluding trypan blue as a percentage of the total number of follicular cells present.

Gradient formation. A continuous isotonic gradient was formed by centrifugation of a mixture containing $45 \%$ Percoll (Pharmacia, Milton Keynes, UK), 49\% McCoy's 5A medium (with Hepes buffer and antibiotics), 5\% Medium 199 (concentrated $\times 10$; Gibco, Uxbridge, UK) and $1 \%$ fetal calf serum (Sigma, Poole, UK), heat inactivated for $30 \mathrm{~min}$ at $56^{\circ} \mathrm{C}$ ) at $25000 \mathrm{~g}$ for $60 \mathrm{~min}$ at $4^{\circ} \mathrm{C}$. The gradients were formed in sterile polyallomer tubes. The volume of each gradient was $30 \mathrm{ml}$ or $7 \mathrm{ml}$ in $50 \mathrm{ml}$ or $10 \mathrm{ml}$ tubes, respectively; however, since the diameters of the tubes were different, the overall length of the gradient was the same in each case $(63.5 \pm 1.44 \mathrm{~mm})$ and results were directly comparable. A reduction in volume was introduced during the study to increase the percentage recovery of viable cells, which was very low at the larger volume (see 'Results'), and a choice of tubes and volumes was made for continuity of results. No effect of this change in volume upon results was discerned.

Gradients formed in opposite positions on the rotor were treated as 'control' and 'test' as follows. For control gradients, a volume $\leqslant 5 \%$ of the total gradient volume, of density marker beads (densities $1.018-1 \cdot 141 \mathrm{~g} / \mathrm{ml}$; Pharmacia, Milton Keynes, UK) was layered over the gradient. For test gradients, a similar volume of the prepared granulosa cell suspension was layered over the gradient. Both tubes were recentrifuged at $500 \mathrm{~g}$ for $20 \mathrm{~min}$ at $4^{\circ} \mathrm{C}$. During this centrifugation, the marker beads sedimented to the level at which their density was equal to that of the surrounding medium, resulting in a series of bands. The distances of the bands from the meniscus of the control gradient were plotted, giving a density profile by which distance could be converted to density for subsequent analysis of the test gradient.

Fraction collection. Fractions were collected at room temperature by piercing the base of the tube using a 23-gauge needle and allowing the gradient to drip into sterile plastic tubes. Fractions amounted to $1 \mathrm{ml}$ or $0.233 \mathrm{ml}$ for the $30 \mathrm{ml}$ and $7 \mathrm{ml}$ gradients respectively. Collection of all fractions was completed in approximately $45 \mathrm{~min}$. To remove the Percoll, 3-4 ml McCoy's 5A medium were added to each fraction. After mixing, the tubes were centrifuged at $2000 \mathrm{~g}$ for $10 \mathrm{~min}$ in a swing-out rotor, the supernatant was removed and the process repeated. Finally, each fraction was resuspended in a volume of $0.25 \mathrm{ml} \mathrm{McCoy's} 5 \mathrm{~A}$ medium containing penicillin $(100 \mathrm{IU} / \mathrm{ml})$, streptomycin $(100 \mu \mathrm{g} / \mathrm{ml})$, Hepes buffer $(25 \mathrm{~mm})$ and heat-inactivated fetal calf serum $(10 \%)$, hereafter referred to as Medium $\mathrm{A}$.

Tissue culture. The fractions were cultured in one of two ways. Either, volumes of $0.05 \mathrm{ml}$ were removed and cultured to produce 4 replicates per fraction made up to a total volume of $0.25 \mathrm{ml}$ with Medium $\mathrm{A}$. The remaining $0.05 \mathrm{ml}$ of each fraction was used for cell counting using a haemocytometer and assessment of viability by exclusion of trypan blue. Alternatively, equal numbers of cells from each fraction, counted using a haemocytometer, were cultured at a concentration of 10000 viable cells $/ \mathrm{ml}$, to compare with the results of the previous experiments in which the numbers of cells cultured from each fraction varied. Cultures were maintained at $37^{\circ} \mathrm{C}$ in an humidified atmosphere of $5 \% \mathrm{CO}_{2}$ in air, $24 \mathrm{~h}$ was allowed for cells to settle before media were replaced and precursors and hormonal supplements were added.

Analysis of fractions. Human chorionic gonadotrophin (hCG, Profasi; Serono Laboratories, Welwyn Garden City, UK; $50 \mathrm{mi} . \mathrm{u} . / \mathrm{ml}$ ) was incorporated into cultures as a luteal stimulant. Both pregnenolone and androstenedione (Sigma; $1 \times 10^{-7} \mathrm{M}$ ) were added as steroid precursors. Cells were cultured for at least 2 days, with media replaced daily. Spent media were stored at $-20^{\circ} \mathrm{C}$. Assays of progesterone and oestradiol in supernatants were made using the media removed after 2 days in culture and exposure to hormones for $24 \mathrm{~h}$. This period was chosen since previous experiments had shown that preculture for $24 \mathrm{~h}$ in a basal medium allowed the cells to regain responsiveness to $\mathrm{hCG}$. Assays were performed using Serona MAIA radioimmunoassay kit reagents (Woking, UK) employing magnetic separation. This method had previously been validated (Hartshorne, 1989a). The sensitivities, intra- and interassay coefficients of variation for the assays were respectively: progesterone, $0.08 \mathrm{ng} / \mathrm{ml}, 6.3 \%, 13.9 \%$; oestradiol, $15 \mathrm{pg} / \mathrm{ml}$, $7 \cdot 6 \%, 11 \cdot 1 \%$. 
The results relating to steroid secretion were calculated relative to the number of cells per fraction since reliable estimates could not be made by protein assay or trypsinization and division of cells in vitro was not observed (data not shown).

The different fractions were examined by phase-contrast microscopy in vitro. Following culture, cells were washed in phosphate-buffered saline and fixed using methanol or a fixative containing formaldehyde ( $1 \%)$, glutaraldehyde $(1 \%)$ and cetyl pyridinium chloride (CPC; $1 \%)$. CPC preserved the glycoprotein matrix which was subsequently stained using Alcian blue in $3 \%$ acetic acid $\left(\mathrm{pH}^{2} 5\right.$ ). For routine morphological analysis, however, Giemsa or Mayer's haematoxylin stains were used.

Statistical analysis. Differences between fractions or populations were assessed using the Kruskal-Wallis test, paired $t$ test or Student's $t$ test.

\section{Results}

\section{Gradient parameters}

The gradient profiles obtained are shown in Fig. 1. Follicular cells were found from 1.02 and $1.08 \mathrm{~g} / \mathrm{ml}$, the region of greatest resolution.

Red blood cells consistently eluted in the 7 th or 8 th fraction of gradients. The majority of white blood cells collected at the limit of highest density of the granulosa cells, $(\geq 1.08 \mathrm{~g} / \mathrm{ml})$ in agreement with the results of others (Ali et al., 1982; Kauffman et al., 1983).

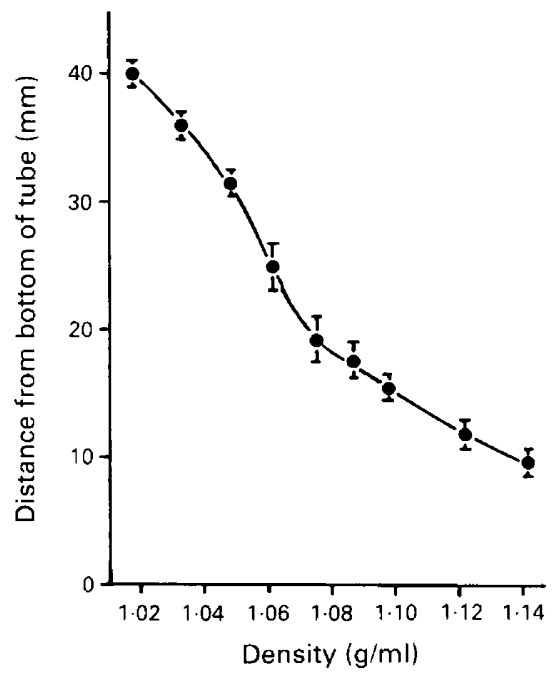

Fig. 1. Continuous density gradient in $45 \%$ Percoll centrifuged at $25000 \mathrm{~g}$ for $60 \mathrm{~min}$. Values are mean \pm s.d., for 16 gradients.

\section{Density profiles of follicular cells}

A total of 0.15 to $1.6 \times 10^{6}$ viable follicular cells was added to each gradient. During centrifugation, fractionation and washing, cell viability decreased from a mean of $82 \%$ to $70 \%$. The mean recovery rates of viable cells using gradients of volumes $30 \mathrm{ml}$ and $7 \mathrm{ml}$ were 18.5 and $35.7 \%$ respectively. Dead cells were found at densities lower than viable cells of the same type and their fractionated profile mirrored that of the viable cells. There were no differences in the proportions 
of dead cells amongst the granulosa populations discussed below as determined by analysis of the areas under the curves.

When cells from a single follicle were fractionated, there was typically one major peak, with one smaller peak on each side. These bands were termed A, B and C where A had the highest and C the lowest density. The proportions of cells in each peak varied considerably in different samples. Examples of 2 fractionated follicles are shown in Fig. 2 (i, ii). Pooling 2 or 3 follicles from the same patient produced similar profiles although the peaks were slightly broader, suggesting that interfollicle variations were present but minor. Such results were therefore included in the calculations of mean density and distribution of cells amongst the populations.

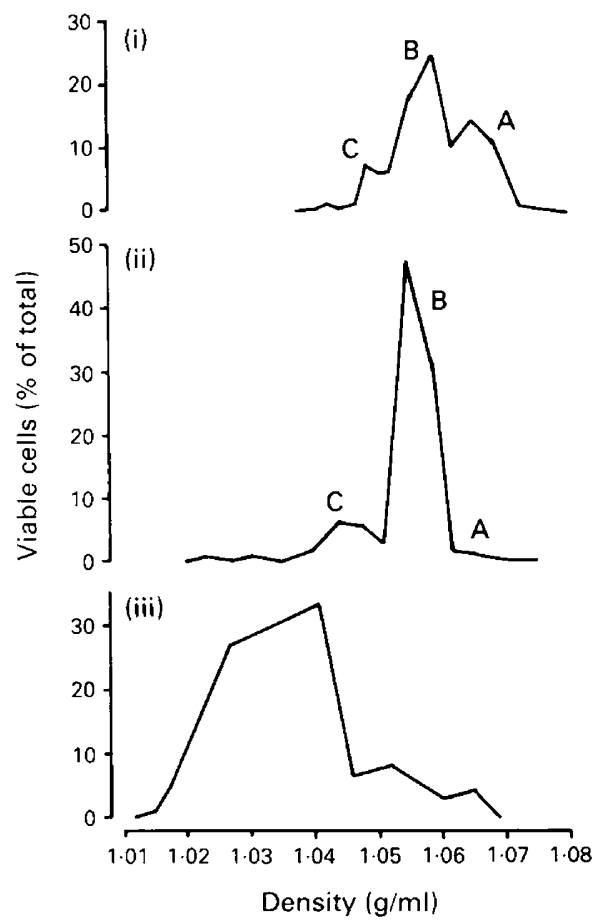

Fig. 2. Density profiles of aspirated granulosa cells. (i, ii) Two individual follicles. The three populations, A, B and C, are visible in both preparations but the proportions of cells in each category are variable. (iii) Density profile of 13 pooled cumuli from one patient. The majority of cells fall in the range $1.02-1.04 \mathrm{~g} / \mathrm{ml}$, possibly corresponding to population $\mathrm{C}$.

When granulosa cells from 10 follicles of 3 patients were pooled, the profile was much less distinctive, suggesting that variations between patients had obscured the major peaks of the individual follicles.

The mean densities of Peaks A, B and C are shown in Table 1. Band C was absent in 3 of the 11 preparations but its density when present was significantly different from that of Band $B$. It is possible that Band $\mathrm{C}$ could be an artefact, but, with this caveat, data concerning this band will be presented as a separate population.

Table 1 also shows the mean proportions of cells in each fraction, calculated by manual measurement of the areas under the curves. One preparation was omitted due to technical difficulties.

Figure 2(iii) shows the profile from fractionating the pooled cumuli of one patient: most cells were found at 1.02 to $1.04 \mathrm{~g} / \mathrm{ml}$, with fewer cells of higher densities. 
Table 1. Characteristics of the three bands of human follicular cells obtained after density gradient centrifugation

\begin{tabular}{lcrcr}
\hline Band & $\begin{array}{c}\text { Mean density } \\
(\mathrm{g} / \mathrm{ml})\end{array}$ & $n_{\dagger}$ & $\begin{array}{c}\text { Mean proportion } \\
\text { of cells } \\
(\%)\end{array}$ & $n_{\ddagger}^{*}$ \\
\hline A & $1.061 \pm 0.002^{*}$ & 11 & $19 \cdot 5 \pm 14.1 \S$ & 9 \\
B & $1.044 \pm 0.009^{*}$ & 11 & $68.5 \pm 11.98$ & 9 \\
C & $1.034 \pm 0.011^{*}$ & 8 & $16.4 \pm 7.39$ & 7 \\
\hline
\end{tabular}

Results with similar symbols are significantly different $(P<0.001$, Kruskal-Wallis test $)$.

$\dagger$ Number of preparations showing Bands A, B or C.

$\ddagger$ Number of preparations permitting calculations of 'area under curve' data.

\section{Morphological characteristics}

General appearance. During the initial counting of cells in the fractions, no obvious differences in size, appearance or viability were noted. When examined under phase contrast, cells appeared healthy and granular, with minimal debris in all fractions.

Subjective analysis of morphology after 2 days in vitro showed minor differences in the cells of different bands. Cells in Band $\mathrm{A}$ were well attached and spread onto the substrate but with few cytoplasmic extensions and pseudopodia. Cells in Band B were more fibroblastic in appearance, slightly less flattened and frequently associated into groups with numerous cytoplasmic connections between cells. Cells of Band $\mathrm{C}$ were more spread and similar to Band $\mathrm{A}$, but with a greater incidence of cytoplasmic projections, either as pseudopodia or more bulbous evaginations.

Glycosaminoglycan staining. Typical results of the subjective analysis of cultured fractions stained with Alcian blue are shown in Table 2. Fractions of density 1.047 to $1.057 \mathrm{~g} / \mathrm{ml}$ stained most intensely, corresponding in this follicle to Band B. Bands A and C were stained to a lesser extent.

Table 2. Example of intensity of Alcian blue staining of fractionated granulosa cells

\begin{tabular}{lccc}
\hline Fraction & Band & $\begin{array}{c}\text { Density } \\
(\mathrm{g} / \mathrm{ml})\end{array}$ & $\begin{array}{c}\text { Alcian blue staining } \\
(0 \text { to } 4)\end{array}$ \\
\hline 10 & A & 1.0620 & 1 \\
11 & A & 1.0590 & 1 \\
12 & B & 1.0565 & 4 \\
13 & B & 1.0545 & 3 \\
14 & B & 1.0515 & 3 \\
15 & B & 1.0495 & 2 \\
16 & B & 1.0470 & 2 \\
17 & C & 1.0450 & 2 \\
18 & C & 1.0430 & 1 \\
19 & C & 1.0410 & 0 \\
\hline
\end{tabular}

\section{Steroid secretion}

Due to the variability in the steroidogenic activity of mature stimulated follicles of each woman (unpublished), only cells fractionated from single follicles were used for assessment of steroid secretion. Six follicles, one each from 6 patients, were examined in this way and the pooled cumulus cells were also subjected to steroid analysis. Granulosa cell steroid production is known to 
show high interindividual variability in both natural and stimulated cycles and so results were analysed individually.

When cells were cultured at concentrations reflecting the prominence of the fraction, the unequal cell numbers affected the steroid secretion, despite the calculation of results on a per cell basis, and this method of culture was abandoned.

Two follicles were cultured using equal numbers of cells from each fraction. Under these conditions, differences amongst the three populations $\mathrm{A}, \mathrm{B}$ and $\mathrm{C}$ were evident and the steroid profile of one follicle is shown in Fig. 3. Bands A and B showed similar basal secretion of progesterone, but Band $\mathrm{C}$ showed approximately $62 \%$ of the levels obtained in Band B. Oestradiol secretion was also similar in Bands $\mathrm{B}$ and $\mathrm{A}$ but Band $\mathrm{C}$ showed a markedly lower oestradiol output, approximately $20 \%$ of that of Bands $\mathrm{A}$ and $\mathrm{B}$.

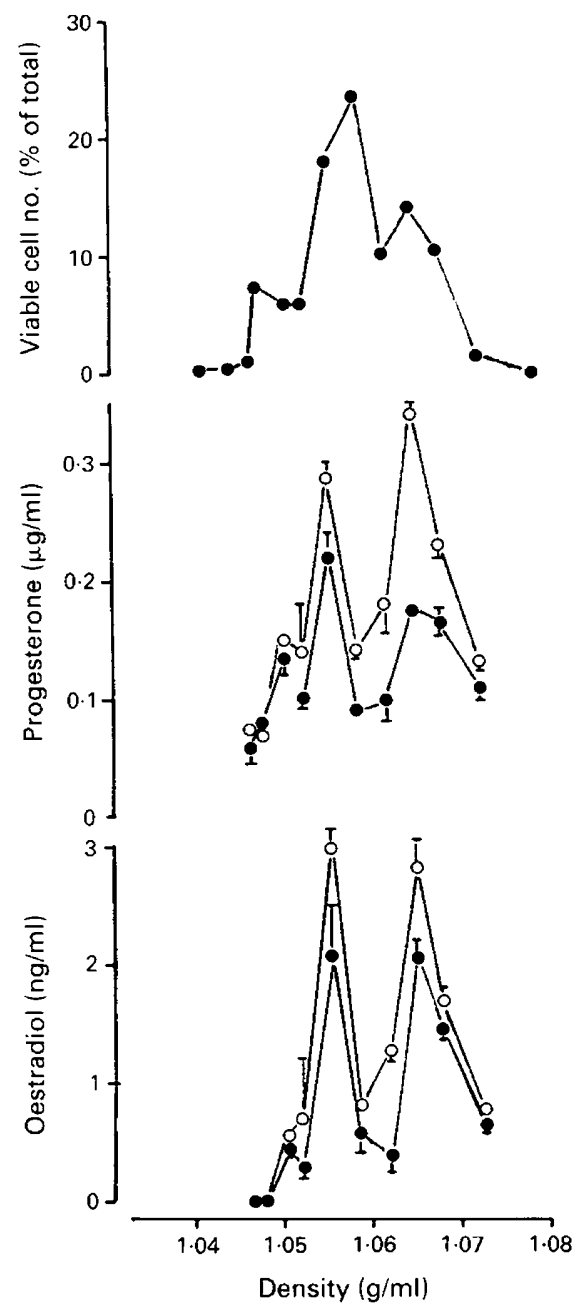

Fig. 3. Representative results of basal and stimulated steroid secretion by granulosa cell populations in one follicular preparation: (i) shows the number of cells in each fraction, (ii) and (iii) show progesterone and oestradiol production respectively. Basal steroid secretion in the presence of precursors (pregnenolone $10^{-7} \mathrm{M}$; androstenedione $10^{-7} \mathrm{M}$ ). $\bigcirc$ Steroid secretion in the presence of precursors and hCG $(50 \mathrm{mi} . \mathrm{u} . / \mathrm{ml})$. Values are mean \pm range of duplicate wells. 
Progesterone production was stimulated in Bands A and B by approximately $90 \%$ and $53 \%$ respectively whereas Band $\mathrm{C}$ was increased by less than $10 \%$ (Fig. 3). Oestradiol secretion was increased to approximately $140 \%$ of the basal level in Bands A and B while Band C was unresponsive to hCG. The results of different preparations were qualitatively similar, although minor quantitative variations were observed. No differences or trends in the progesterone:oestradiol ratio were seen amongst the fractions. No variations could be correlated with stimulation profiles or other parameters of patient treatment, probably because of the large interindividual differences in patients and the small numbers so far examined.

Basal steroid secretion by the cumulus cells is shown in Fig. 4. Most cells showed low secretion of steroids with a minor band, possibly corresponding to Band B, showing the greatest secretion of both progesterone and oestradiol. Another, denser band, possibly corresponding to Band A, showed very low secretion per cell. These denser bands might represent contaminants of the cumulus from other aspirated cells. The response to hCG was erratic (data not shown).

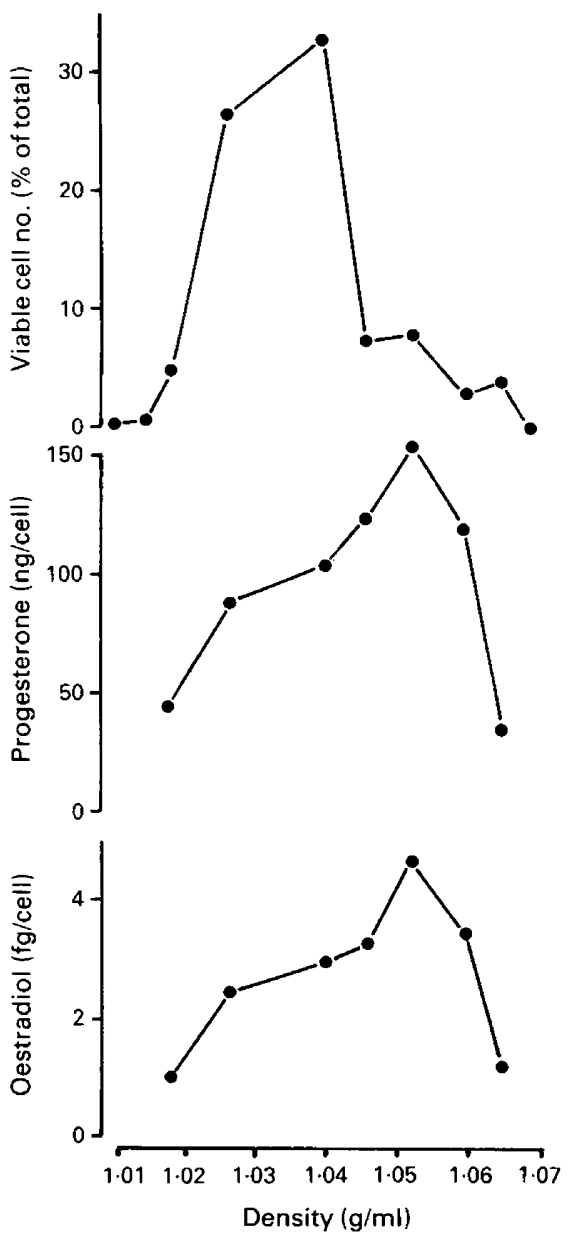

Fig. 4. Basal steroid secretion in terms of progesterone and oestradiol production per cell of fractions obtained from 13 pooled cumuli from one patient. 
Five of the 6 follicles fractionated individually had corresponding samples of follicular fluid. The concentrations of progesterone, oestradiol and the progesterone/oestradiol ratio were plotted against the observed densities of the bands in each follicle. No significant correlation was obtained, despite a slight tendency for a reduction in density with increasing levels of follicular progesterone (Fig. 5).

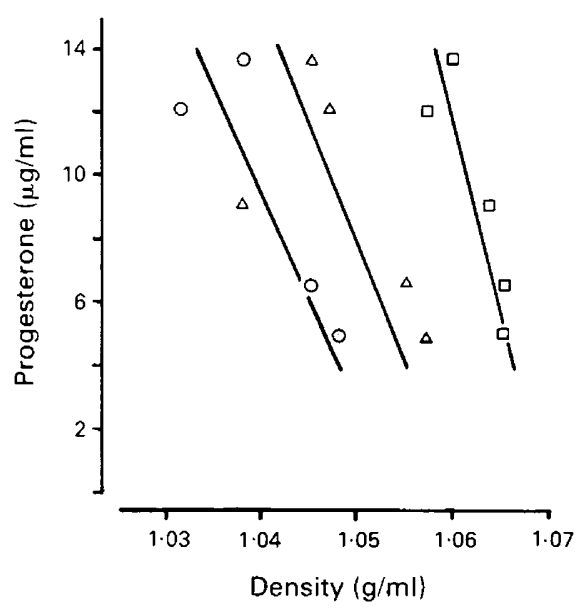

Fig. 5. Concentrations of progesterone in follicular fluid versus densities of granulosa cell populations in individual follicles. $\square$ Band $\mathrm{A}, \triangle \mathrm{B}$ and $\mathrm{B}, \bigcirc \mathrm{B}$ and $\mathrm{C}$.

\section{Discussion}

Isopycnic density gradient centrifugation separates cells according to density, irrespective of size. Cell density relates to the balance of lipids or other 'buoyant' substances and denser factors, such as compact nuclear material. Granulosa cell luteinization involves increased lipid and steroid production, which might influence cell density (Lahteenmaki et al., 1982). Moreover, the variety of other substances, such as proteoglycans, produced by the granulosa cells, might result in subpopulations when separated by density.

Three populations of human follicular cells were obtained having mean densities of $1.061,1 \cdot 044$ and $1.032 \mathrm{~g} / \mathrm{ml}$, named $\mathrm{A}$ to $\mathrm{C}$ respectively. The bands were considered as separate populations and different properties suggested that functional differences might be present. When an enriched population of cumulus cells was pooled and fractionated, a broad major band resulted with a density of $1.02-1.04 \mathrm{~g} / \mathrm{ml}$. This peak corresponded most closely to follicular Band C, although the $24 \mathrm{~h}$ prior culture might have slightly reduced the cumulus cell density (Lahteenmaki et al., 1982) or adherent or phagocytosed sperm heads (Pijnenborg et al., 1985) might have had the opposite effect. These factors cannot be excluded from the present study, but as a pointer towards the identity of the bands obtained it was considered that such data were worthwhile. Band $\mathrm{C}$ was present in only 8 of the 11 preparations. Possibly, the vigour of aspiration may slough cells from the cumulus mass during its passage through the aspiration needle, thus introducing this variability into the results.

Alcian blue ( $\mathrm{pH} 2.5$ ) was used to stain proteoglycans. Proteoglycans are produced particularly by cumulus and antral cells lining the cavity during follicular fluid formation. Staining was most intense in the least dense fractions of Band B but all bands showed some staining and the differences between bands were not distinct. The results suggest that cells of Band $B$ are the most active in proteoglycan production and as such were probably amongst those lining the antrum of the follicle in vivo. 
Few workers have examined granulosa cells using density gradient centrifugation. Lahteenmaki et al. (1982) found two cell populations of densities 1.03 and $1.05-1.08 \mathrm{~g} / \mathrm{ml}$ in pig preovulatory follicles but their preparation did not distinguish between cumulus or antral cells. Their lower density population contained fewer cells and might correspond to the cumulus cells, with the higher density band representing the antral cells, but this cannot be proven. However, the agreement between the densities of the bands is encouraging.

No other study has investigated preovulatory follicles, but Kolena et al. (1983), using pig immature follicles, produced an essentially similar density profile though somewhat obscured by dead cells. Kasson et al. (1985), working on diethylstilboestrol-treated immature rats, also found three populations of granulosa cells but the profile was different, with two major bands of slightly differing densities, and one minor, low density population.

The steroid secretion of the three populations presented here was also examined. The steroid production per cell was clearly affected by the numbers of cells present and so similar cell numbers from each fraction were cultured for endocrine evaluation. Progesterone was produced by all bands, with highest levels in Bands $\mathrm{A}$ and $\mathrm{B}$. This is consistent with Band $\mathrm{C}$ representing the cumulus cells which secrete less progesterone (Magnussom et al., 1982). Band C also responded poorly to hCG in both progesterone and oestradiol secretion. Amsterdam et al. (1975) demonstrated a gradient of hCG receptor density from low in the centre to high at the periphery of the follicle, possibly accounting for the low response of Band C to hCG. It could be supposed that Band $\mathrm{A}$, which was the most responsive to hCG, represents the most peripheral of the aspirated cells, and Band $\mathrm{B}$, with a lesser response to hCG, corresponds to cells from the antral region, although it is unclear why distinct populations are evident rather than a continuum. The possibility that Band A represents mural cells or even the most precocious invading thecal cells should not be overlooked. The fractionated pooled cumulus cells produced progesterone and oestradiol, but single cumuli contained too few cells to be analysed individually, so comparisons of cumulus and antrum from the same follicle could not be made.

Lahteenmaki et al. (1982) found the highest basal progesterone production in their high density fraction but responsiveness to hCG was not analysed. Kolena et al. (1983) showed the greatest basal progesterone production by the intermediate density band of three, with the remaining two bands secreting similar levels of progesterone. The intermediate band also had most hCG receptors, with fewer in the densest band, although again, responses to hCG were not assessed. These results do not favour the hypothesis that the densest fraction could be the outermost aspirated cells, but small pig follicles were used and the results might not reflect the mature human follicle.

The densities of the subpopulations may relate to the levels of progesterone in the corresponding follicular fluids. Although not achieving significance, the results suggest that, with increasing luteinization, their densities may decrease, possibly due to steroidogenic activity and accumulation of lipid. Indeed, Lahteenmaki et al. (1982) found the densities of granulosa cell populations to decrease with culture. The steroid content of follicular fluid is also related to the stimulation protocol applied (Hartshorne, 1989b), but no relationships between stimulation protocols and granulosa cell profiles were observed.

The results presented suggest that subpopulations of human follicular cells exist, differing in densities, appearance in culture, basal steroid secretion and sensitivity to hCG. Continued study might provide evidence of physiological differences between populations and their role in the preovulatory follicle and subsequent corpus luteum. Furthermore, recombination of the different populations might suggest new concepts of co-operative development amongst the follicular cells.

I thank Professor R. G. Edwards for supervision of this project and the embryological staff of Bourn Hall Clinic for assistance with the collection of material for analysis. This work was supported by a grant from Ares Serono NV and the Edwards Steptoe Research Trust. 


\section{References}

Ali, F.M.K., May, A., McLaren, G.D. \& Jacobs, A. (1982) A two-step procedure for obtaining normal peripheral blood $\mathrm{T}$ lymphocytes using continuous equilibrium density gradient centrifugation on Percoll. $J$. Immunological Methods 49, 185-191.

Amsterdam, A., Koch, Y., Lieberman, M.E. \& Lindner, H.R. (1975) Distribution of binding sites for human chorionic gonadotrophin in the preovulatory follicle of the rat. J. Cell Biol. 67, 894-900.

Erickson, G.F., Hofeditz, C., Unger, M., Allen, W.R. \& Dulbecco, R. (1985) A monoclonal antibody to a mammary cell line recognizes two distinct subtypes of ovarian granulosa cells. Endocrinology 117, $1490-1499$.

Gilula, N.B., Epstein, M.L. \& Beers, W.H. (1978) Cell to cell communication and ovulation. A study of the cumulus-oocyte complex. J. Cell Biol. 78, 58-75.

Hartshorne, G.M. (1989a) Steroid production by the cumulus: Relationship to fertilization in vitro. Hum. Reprod. 4, 742-745.

Hartshorne, G.M. (1989b) Preovulatory follicular fluid: relationships to ovarian stimulation protocol, fertilization, and sperm penetration in vitro. Fert. Steril. 52, 998-1005.

Howles, C.M., Macnamee, M.C. \& Edwards, R.G. (1987) Follicular development and early luteal phase function of conception and non-conception cycles after human in vitro fertilization: endocrine correlates. Hum. Reprod. 2, 569-571.

Kasson, B.G., Meidan, R., Davoren, J.B. \& Hsueh, A.J.W . (1985) Identification of subpopulations of rat granulosa cells. Sedimentation properties and hormonal responsiveness. Endocrinology 117, 1027-1034.

Kauffman, H.G., Levering, P.R. \& DeVries, K. (1983) A single centrifugation step method for the simultaneous separation of different leukocytes with special refer- ence to basophilic leukocytes. J. Immunol. Methods $57,1-7$.

Kolena, J., Kiss, A. \& Channing, C.P. (1983) Purification of porcine granulosa cells by continuous Percoll gradient. Experientia 39, 908-909.

Lahteenmaki, P., Lobo, R., Marrs, R.P., Gibbons, W.E., Nakamura, R.M. \& diZerega, G.S. (1982) Characterization of porcine granulosa cells by isopycnic gradient centrifugation. Biol. Reprod. 27, 633-640.

Macnamee, M.C., Howles, C.M., Edwards, R.G. \& Taylor, P.J. (1989) Short term LHRH agonist treatment: A novel ovarian stimulation regimen for in vitro fertilization. Fert. Steril. 52, 264-269.

Magnusson, C., Billig, H., Eneroth, P., Roos, P. \& Hillensjo, T. (1982) Comparison between the progestin secretion responsiveness to gonadotrophins of rat cumulus and mural granulosa cells in vitro. Acta endocr. Copenh. 101, 611-616.

Pijnenborg, R., Gordts, S., Ongkowidjojo, R. \& Brosens, I. (1985) Sperm phagocytosis by corona cells in a human in vitro fertilization system. Ann. NY Acad. Sci. 442, 310-317.

Telfer, E., Ansell, J.D., Taylor, H. \& Gosden, R.G. (1988) The number of clonal precursors of the follicular epithelium in the mouse ovary. J. Reprod. Fert. 84, $105-110$.

Zoller, L.C. \& Weisz, J. (1978) Identification of cytochrome P-450 and its distribution in the membrana granulosa of the preovulatory follicle using quantitative cytochemistry. Endocrinology 103, 310-313.

Zoller, L.C. \& Weisz, J. (1979) A quantitative cytochemical study of glucose-6-phosphate dehydrogenase and delta 5,3 beta-hydroxy steroid dehydrogenase activity in the membrana granulosa of the ovulable type of follicle of the rat. Histochemistry 62, 125-135.

Received 22 January 1990 